\title{
Analyses of Polyethylene Glycol (Mono- and Di- Methyl) Ether Adsorbed on CaA, NaX, NaY, and ZSM-5 Synthetic Zeolites by Infrared and Raman Spectroscopies
}

\author{
Nuri ÖZTÜRK ${ }^{1 *}$, Semiha BAHÇELİ ${ }^{2}$
}

\begin{abstract}
The adsorptions of polyethylene glycol monomethyl ether (PEGMME) and polyethylene glycol dimethyl ether (PEGDME) on CaA, NaX, NaY, and ZSM-5 zeolites have been analyzed by using experimental FT-IR and Raman spectroscopies. The vibration wavenumbers of polymers adsorbed on zeolites have been reported and the adsorption properties of zeolites with different molecular sizes and cations have been compared. Disappearing of some vibration modes of polymers or shifts to the higher and lower frequency region after the polymers have been adsorbed on zeolites; indicates an interaction between polymers and zeolites. By considering the obtained experimental spectral results we can suggest that the source of adsorption of polymers on zeolites can be based on the interactions between $\mathrm{OH}$ groups or oxygen atoms settled in polymer chains and the silanol hydroxyl groups on the surface of each zeolite.
\end{abstract}

Keywords: Vibrational spectroscopy, Zeolite, Adsorption, Polymer.

\section{CaA, NaX, NaY ve ZSM-5 Sentetik Zeolitleri Üzerine Adsorbe Edilen Polietilen Glikol (Mono- ve Di- Metil) Eterin Kırmızıaltı ve Raman Spektroskopileri ile Analizi}

\section{$\ddot{\mathbf{O} z}$}

Polietilen glikol monometil eter (PEGMME) ve polietilen glikol dimetil eterin (PEGDME) CaA, NaX, NaY ve ZSM-5 zeolitleri üzerindeki adsorpsiyonları deneysel FT-IR ve Raman spektroskopileri kullanılarak analiz edilmiştir. Zeolitler üzerine adsorbe edilen polimerlerin titreşim dalgasayıları bildirilmiş ve farklı moleküler boyutlara ve katyonlara sahip zeolitlerin adsorpsiyon özellikleri karşılaştırılmıştır. Polimerlerin bazı titreşim modlarının kaybolması veya polimerler zeolitler üzerine adsorbe edildikten sonra daha yüksek ve daha düşük frekans bölgesine kaymalar; polimerler ve zeolitler arasındaki etkileşimin varlığını göstermektedir. Elde edilen deneysel spektral sonuçları dikkate alarak, polimerlerin zeolitler üzerindeki adsorpsiyon kaynağının, $\mathrm{OH}$ grupları veya polimer zincirlerine yerleşmiş oksijen atomları ile her bir zeolitin yüzeyindeki silanol hidroksil grupları arasındaki etkileşimlere dayandırılabileceğini söyleyebiliriz.

Anahtar Kelimeler: Titreşim spektroskopisi, Zeolit, Adsorpsiyon, Polimer.

\footnotetext{
${ }^{1}$ Giresun University, Dereli Vocational School, Giresun, Türkiye, nuri.ozturk@giresun.edu.tr

${ }^{2}$ University of Turkish Aeronautical Association, Department of Astronautical Engineering, Ankara, Türkiye, s.bahceli80@gmail.com

${ }^{1}$ https://orcid.org/ 0000-0001-8742-0160 ${ }^{2}$ https://orcid.org/ 0000-0002-5614-325X
} 


\section{Introduction}

The zeolites are crystalline aluminosilicates that exhibit three-dimensional structures interconnecting frameworks of $\mathrm{SiO}_{4}$ and $\mathrm{AlO}_{4}$ tetrahedra, being connected by sharing one oxygen atom between two tetrahedra. Low $\mathrm{SiO}_{2}$ ratio normally provides stronger adsorbance for polar molecules and powerful cation exchange capacity. Conversely, a higher $\mathrm{SiO}_{2}$ ratio generally provides stronger-acid catalytic activity as adsorbents (Cejka, 2007). Zeolites with low and medium Si/Al ratios can be used to remove water from organic materials, while molecular sieves with a high $\mathrm{Si} / \mathrm{Al}$ ratio can be used to remove organic materials from water. In other words, zeolites are separated from each other by structural differences in their unit cell and the structural properties of zeolites are highly described in the literature. Zeolites are used as ion exchangers because their cations are bound by weak bonds and ions can be easily exchanged. Zeolites which are used as selective catalysts, ion exchangers, and adsorbents in the oil refinery, petrochemical, and chemical process industries, are the best known microporous molecular sieves. When zeolites are heated, the water molecules in their pores easily leave the zeolitic structure. Depending on the pore structures of the zeolites, it is known that they can adsorb molecules smaller than their pore sizes into the spaces inside them and they can adsorb the molecules with large sizes on their surfaces. The unit cells of the synthetic zeolites CaA, $\mathrm{NaX}, \mathrm{NaY}$, and ZSM-5 used in this study consist of $\mathrm{Ca}_{12}\left[\left(\mathrm{AlO}_{2}\right)_{12}\left(\mathrm{SiO}_{2}\right)_{12}\right] \cdot 27 \mathrm{H}_{2} \mathrm{O}$,

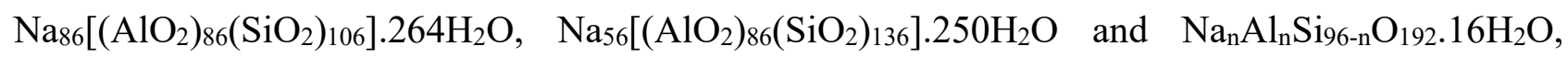
respectively (Öztürk et al., 2005; Thomas and Klinowski, 2007; Öztürk et al., 2010). The pore sizes of the mentioned zeolites are 4-5 $\AA$ for $\mathrm{CaA}, 7-10 \AA$ for $\mathrm{NaX}$ and $\mathrm{NaY}$, and 5-6 $\AA$ for ZSM-5 which consists of two types of crossing and vertical channel systems (Öztürk et al., 2009; Bleken et al., 2011). Most of the newly synthesized synthetic zeolites have larger pore sizes and higher capacity than most natural zeolites, thus allowing applications for larger molecules (Sherman, 1999; Cundy and Cox, 2003; Franus et al., 2014). The catalytic properties of these molecular sieves, which we can think as strong catalysts and sorbents, can be understood by examining the adsorption qualities on their surfaces (Hunger, 1997; Çiçet et al., 2003). Vibration spectroscopy is one of the frequently used methods to determine some properties of zeolites such as absorbent (Şen et al., 2008; Öztürk et al., 2009; Marković et al., 2017; Kumar et al., 2020; Velvarská et al., 2020). Öztürk et al. have investigated the Infrared and SEM analyses of Polyethyleneglycol-400 adsorbed on zeolites NaA, $\mathrm{CaA}, \mathrm{NaX}$ and $\mathrm{NaY}$ zeolites (Öztürk et al., 2009). It seems that our study is in harmony with this study.

This study aims to notice the results of infrared and Raman spectra of two polymers adsorbed on CaA (LTA, type 5A), NaX (FAU, type 13X), NaY (FAU), and ZSM-5 (MFI) synthetic zeolites and the source of adsorption of polyethylene glycol (monomethyl ether) and polyethylene glycol 
(dimethyl ether) on mentioned zeolites. It is seen that the adsorption sources of polymers on zeolites are the interactions between methylene and $\mathrm{OH}$ groups and oxygen atoms of the polymers and the non-acidic silanol hydroxyl group on the surface of zeolites.

\section{Materials and Methods}

\subsection{Materials}

All synthetic zeolites, CaA (Aldrich), NaX (Fluka), NaY (Aldrich), and ZSM-5 (Zeolisyt, Si/Al ratio: 30) have been obtained from commercial sources. Moreover, PEGMME (Fluka) powder and liquid PEGDME (Fluka) have been obtained commercially and used without any purification. Chloroform and ethyl alcohol are used as solvent and purifier to remove residues.

\subsection{Sample Preparation}

First, $\mathrm{CaA}, \mathrm{NaX}$, and $\mathrm{NaY}$ zeolites have been calcined (activated in the oven) at $623 \mathrm{~K}$ for 4 hours, while, ZSM-5 has been activated at $823 \mathrm{~K}$ for 5 hours to be purified from water molecules in their structure and waited for them to cool to room temperature. $100 \mathrm{mg}$ PEGMME powder has been solved in $40 \mathrm{ml}$ chloroform without concentration calculation. Then, $1 \mathrm{~g}$ of each zeolite has been put into $10 \mathrm{ml}$ PEGMME solution and liquid PEGDME separately. After the samples have been stirred and stored for 40 hours for maximum adsorption to occur at room temperature, the mixtures have been filtered and washed three times with chloroform and ethyl alcohol to remove suspension residues. All samples have been left to dry at room temperature.

\subsection{Measurements}

The polymer adsorbed zeolite samples have been compressed as pellets with $\mathrm{KBr}$ for the infrared spectrum. The IR spectra of the samples have been recorded on a Perkin Elmer Spectrum One FT-IR Spectrometer in the transmission mode in the region of $4000-400 \mathrm{~cm}^{-1}$ with a resolution of $4 \mathrm{~cm}^{-1}$ at room temperature. Raman spectra of the samples have been recorded by using a Jasco NRS-3100 micro-Raman Spectrophotometer with 600 lines/mm grating in the region of 4000-150 $\mathrm{cm}^{-1}$ at room temperature. The $785 \mathrm{~nm}$ lines of the diode laser have been used for the excitation of samples. The exposure time for each sample has been taken as 25 seconds and the average of 10 measurements taken. Infrared and Raman spectra of PEGMME and PEGDME have been also taken by the mentioned methods. 


\section{Results and Discussion}

The molecular structures of polymers have been depicted in Figure 1. Infrared (IR) spectra of polyethylene glycol (monomethyl ether) and polyethylene glycol (dimethyl ether) adsorbed on CaA, $\mathrm{NaX}, \mathrm{NaY}$, and ZSM-5 have been given in Figure 2. Similarly, the Raman (R) spectra of polyethylene glycol (monomethyl ether) and polyethylene glycol (dimethyl ether) adsorbed on the mentioned zeolites have been given in Figure 3. On the other hand, the observed wavenumbers and the assignments of vibrational bands have been summarized in Table 1 and Table 2 as well as those of free PEGMME and PEGDME, respectively. According to the tables, we can say that the most characteristic vibration bands of both polymers have been also observed for their adsorbed forms on the mentioned zeolites. As can be seen in Figures 2 and 3, some characteristic peaks of both polymers were generally observed as weak bands in the IR and Raman spectra of zeolites after the adsorption process. When the IR and Raman spectra of pure zeolites are compared with the spectra recorded after the adsorption process on zeolites, the observed extra bands are caused by the adsorbed polymers. The loss of vibration modes of pure polymers or changes in the position of any vibration mode would be a sign of interaction between polymers and synthetic zeolites. In comparison with vibrational bands of free polymers, the shifts at the positions of vibration bands of polymers adsorbed on mentioned zeolites can be concluded to be an interaction between zeolites and polymers. These frequency shifts to lower and higher regions show the presence of adsorption of PEGMME and PEGDME on the mentioned zeolites. Then, the adsorption properties of zeolites with different molecular sizes have been compared. As seen in Table 1, the $\mathrm{CH}_{2}$ and $\mathrm{CH}_{3}$ stretching bands at the interval of 2947-2861 (IR) $\mathrm{cm}^{-1}$ and 2943-2830 (R) $\mathrm{cm}^{-1}$ of free PEGMME have been observed at the interval of 2949-2806 (IR) $\mathrm{cm}^{-1}$ and 2936-2820 (R) $\mathrm{cm}^{-1}$ of adsorbed forms on zeolites. Similarly, as seen in Table 2, these bands have observed at the interval of 2924-2823 (IR) $\mathrm{cm}^{-1}$ and 2937-2823 (R) $\mathrm{cm}^{-1}$ for free PEGDME and at the interval of 2932-2824 (IR) $\mathrm{cm}^{-1}$ and $2880-2828$ (R) $\mathrm{cm}^{-1}$ for adsorbed forms on mentioned zeolites. Likewise; Öztürk et al. observed $\mathrm{CH}_{2}$ symmetric and asymmetric stretching vibrations in the range of $2918-2745 \mathrm{~cm}^{-1}$ in their studies (Öztürk, et al., 2009). Some other vibration band assignments in Table 1 and Table 2 are also in agreement with this study. Moreover, very weak bands of around $2900-3000 \mathrm{~cm}^{-1}$ can be assigned to the presence of $\mathrm{SiOCH}_{3}$, called a chemisorption product, on zeolites (Çiçek et al., 203).

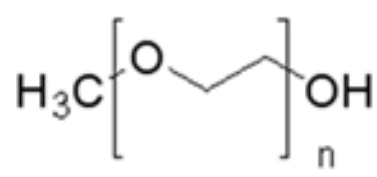

(a)

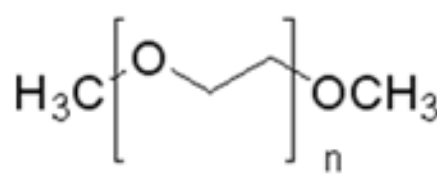

(b)

Figure 1. Molecule structures of a) PEGMME and b) PEGDME 

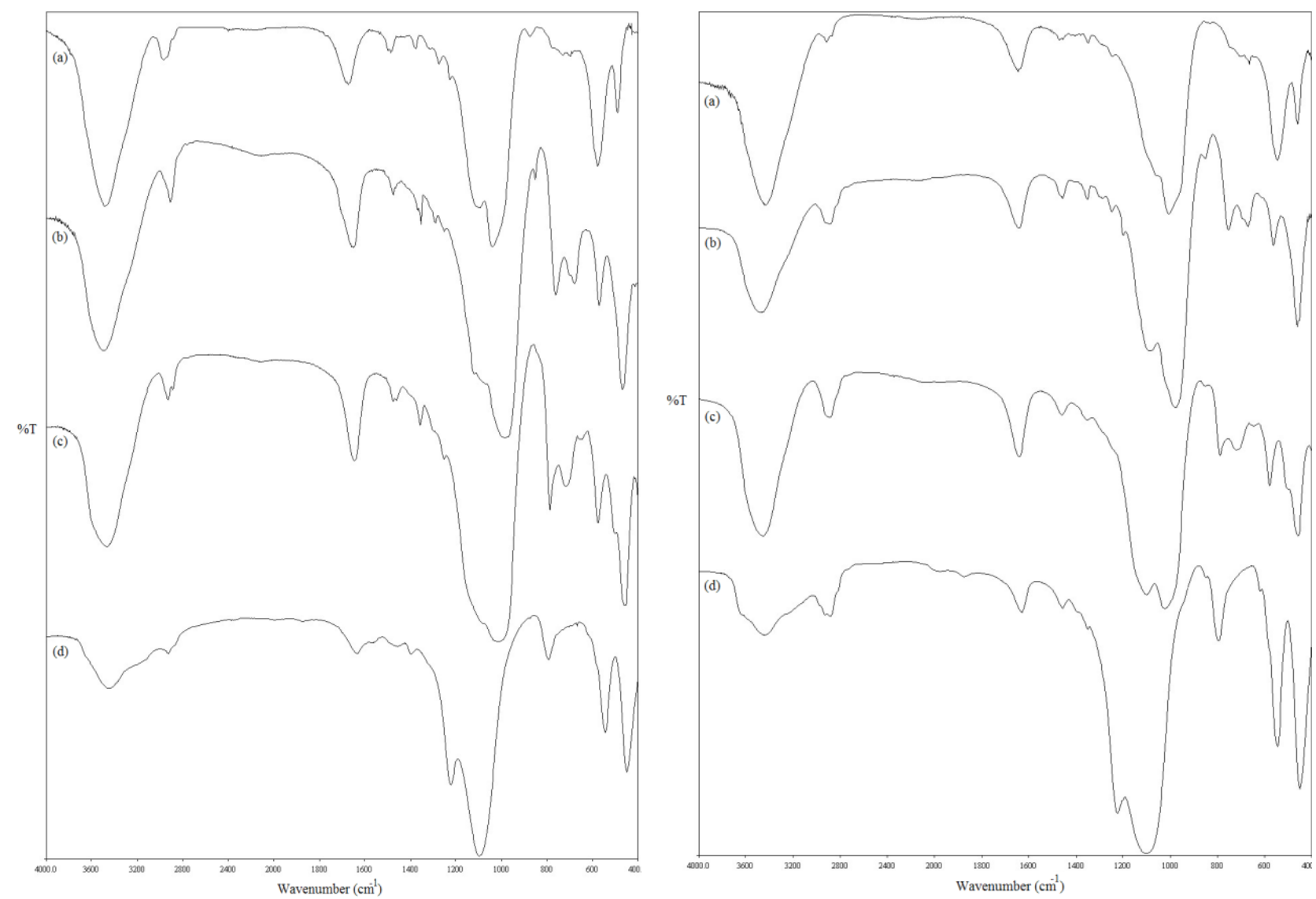

Figure 2. Infrared spectra of PEGMME (left) and PEGDME (right) adsorbed on the a) CaA, b) NaX, c) $\mathrm{NaY}$ and d) ZSM-5 zeolites
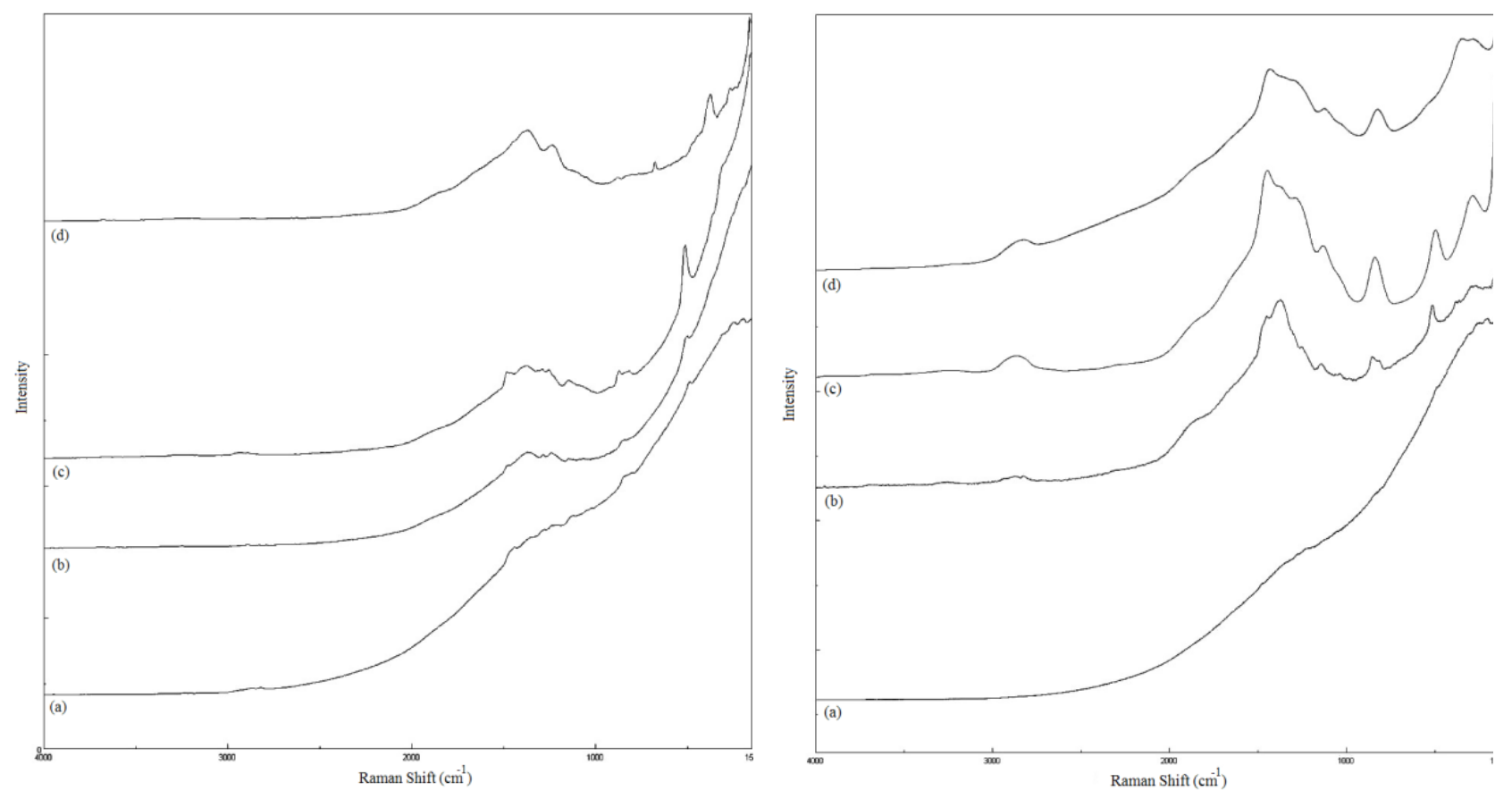

Figure 3. $\mu$-Raman spectra of PEGMME (left) and PEGDME (right) adsorbed on the a) CaA, b) $\mathrm{NaX}, \mathrm{c}) \mathrm{NaY}$ and d) ZSM-5 zeolites 
Table 1. The IR and Raman frequencies $\left(\mathrm{cm}^{-1}\right)$ of PEGMME adsorbed on CaA, NaX, NaY, and ZSM-5 zeolites.

\begin{tabular}{|c|c|c|c|c|c|c|c|c|c|c|}
\hline \multicolumn{2}{|c|}{ PEGMME } & \multicolumn{2}{|c|}{$\underline{\mathrm{CaA}}$} & \multicolumn{2}{|c|}{$\underline{\mathrm{NaX}}$} & \multicolumn{2}{|c|}{$\mathrm{NaY}$} & \multicolumn{2}{|c|}{$\underline{\text { ZSM-5 }}$} & \multirow{2}{*}{ Assignments } \\
\hline$\underline{\mathrm{IR}}$ & $\underline{\text { Raman }}$ & $\underline{\mathrm{IR}}$ & Raman & $\underline{\mathrm{IR}}$ & $\underline{\text { Raman }}$ & $\underline{\mathrm{IR}}$ & $\underline{\text { Raman }}$ & $\underline{\mathrm{IR}}$ & Raman & \\
\hline 2947 w & 2943 w & $2926 \mathrm{~m}$ & - & $2949 \mathrm{sh}$ & - & $2928 \mathrm{~m}$ & $2936 \mathrm{vw}$ & $2928 \mathrm{~m}$ & $2932 \mathrm{vw}$ & $v_{\text {as }}\left(\mathrm{CH}_{3}\right)$ \\
\hline $2881 \mathrm{~s}$ & $2886 \mathrm{~m}$ & $2881 \mathrm{sh}$ & $2870 \mathrm{vw}$ & $2892 \mathrm{~m}$ & $2885 \mathrm{vw}$ & $2887 \mathrm{w}$ & $2892 \mathrm{vw}$ & $2874 \mathrm{sh}$ & $2881 \mathrm{vw}$ & $v_{a s}\left(\mathrm{CH}_{2}\right)$ \\
\hline $2861 \mathrm{vw}$ & $2830 \mathrm{w}$ & $2835 \mathrm{sh}$ & $2820 \mathrm{vw}$ & $2806 \mathrm{sh}$ & - & - & - & - & - & $v_{\mathrm{s}}\left(\mathrm{CH}_{2}\right)$ \\
\hline $1467 \mathrm{~s}$ & $1481 \mathrm{~s}$ & $1473 \mathrm{~m}$ & - & $1468 \mathrm{~m}$ & $1475 \mathrm{w}$ & $1477 \mathrm{~m}$ & $1477 \mathrm{~m}$ & - & - & $\delta_{s}\left(\mathrm{CH}_{2}\right)$ \\
\hline $1456 \mathrm{w}$ & $1447 \mathrm{w}$ & $1458 \mathrm{~m}$ & $1442 \mathrm{w}$ & $1457 \mathrm{w}$ & - & $1460 \mathrm{~m}$ & $1450 \mathrm{vw}$ & $1456 \mathrm{bm}$ & $1448 \mathrm{vw}$ & $\delta\left(\mathrm{CH}_{3}\right)$ \\
\hline $1360 \mathrm{~m}$ & $1362 \mathrm{w}$ & $1357 \mathrm{sh}$ & - & $1360 \mathrm{w}$ & - & $1357 \mathrm{~m}$ & - & - & $1371 \mathrm{bm}$ & $w\left(\mathrm{CH}_{2}\right)$ \\
\hline $1341 \mathrm{~s}$ & - & $1350 \mathrm{~m}$ & - & $1344 \mathrm{~m}$ & - & - & - & $1323 \mathrm{sh}$ & - & $w\left(\mathrm{CH}_{2}\right)$ \\
\hline $1279 \mathrm{~s}$ & $1280 \mathrm{~s}$ & $1294 \mathrm{bw}$ & $1277 \mathrm{w}$ & $1282 \mathrm{~m}$ & $1285 \mathrm{w}$ & $1300 \mathrm{w}$ & $1282 \mathrm{w}$ & - & - & $t\left(\mathrm{CH}_{2}\right)$ \\
\hline $1241 \mathrm{~s}$ & $1234 \mathrm{~m}$ & $1250 \mathrm{~m}$ & - & $1243 \mathrm{~m}$ & - & $1252 \mathrm{w}$ & - & - & $1230 \mathrm{bm}$ & $t\left(\mathrm{CH}_{2}\right)$ \\
\hline $1147 \mathrm{~s}$ & $1141 \mathrm{~m}$ & - & - & $1111 \mathrm{w}$ & - & - & - & - & - & $w\left(\mathrm{CH}_{3}\right)$ \\
\hline- & $1129 \mathrm{sh}$ & - & $1123 \mathrm{w}$ & - & $1144 \mathrm{w}$ & - & - & - & $1124 \mathrm{w}$ & $\rho\left(\mathrm{CH}_{2}\right)$ \\
\hline $1060 \mathrm{~s}$ & $1063 \mathrm{~m}$ & $1071 \mathrm{bm}$ & - & $1063 \mathrm{w}$ & $1067 \mathrm{vw}$ & $1083 \mathrm{bw}$ & - & - & 1046 w & $v(\mathrm{C}-\mathrm{O})$ \\
\hline $947 \mathrm{~m}$ & $934 \mathrm{w}$ & - & - & - & - & - & $921 \mathrm{w}$ & - & - & $v(\mathrm{C}-\mathrm{O}-\mathrm{C})$ \\
\hline $841 \mathrm{~s}$ & $844 \mathrm{~s}$ & $850 \mathrm{~m}$ & $838 \mathrm{w}$ & $843 \mathrm{~m}$ & $839 \mathrm{w}$ & $844 \mathrm{sh}$ & $862 \mathrm{~m}$ & - & $872 \mathrm{w}$ & $\rho\left(\mathrm{CH}_{2}\right)$ \\
\hline- & 803 vw & - & $803 \mathrm{w}$ & - & 812 vw & - & $807 \mathrm{w}$ & - & - & $w\left(\mathrm{CH}_{2}\right)$ \\
\hline
\end{tabular}

v: very; s: strong; m: medium; w: weak; sh: shoulder; b: broad; $v$ : stretching; $\delta$ : in-plane bending; $\delta_{s}$ : scissoring; $w$ : wagging; $t$ : twisting; $\rho$ : rocking

Besides, there are some significant changes for the $\mathrm{CH}_{2}$ in-plane bending, scissoring, wagging, twisting, and rocking bands among free and adsorbed polymers as seen in Tables 1 and 2. The shifts to higher or lower frequency regions in the IR and $\mu$-Raman spectra of polymers adsorbed on the mentioned zeolites indicate that the silanol hydroxyl groups on the surface of zeolites interact with methylene groups of adsorbed polymers by hydrogen bonding (Silverstein and Webster, 1997; Stuart, 2004).

Table 2. The IR and Raman frequencies $\left(\mathrm{cm}^{-1}\right)$ of PEGDME adsorbed on CaA, NaX, NaY, and ZSM-5 zeolites.

\begin{tabular}{|c|c|c|c|c|c|c|c|c|c|c|}
\hline \multicolumn{2}{|c|}{$\underline{\text { PEGDME }}$} & \multicolumn{2}{|c|}{$\underline{\mathrm{CaA}}$} & \multicolumn{2}{|c|}{$\underline{\mathrm{NaX}}$} & \multicolumn{2}{|c|}{$\underline{\mathrm{NaY}}$} & \multicolumn{2}{|c|}{ ZSM-5 } & \multirow{2}{*}{ Assignments } \\
\hline$\underline{\mathrm{IR}}$ & $\underline{\text { Raman }}$ & $\underline{\mathrm{IR}}$ & $\underline{\text { Raman }}$ & $\underline{\mathrm{IR}}$ & $\underline{\text { Raman }}$ & $\underline{\mathrm{IR}}$ & $\underline{\text { Raman }}$ & $\underline{\mathrm{IR}}$ & $\underline{\text { Raman }}$ & \\
\hline $2924 \mathrm{sh}$ & $2937 \mathrm{sh}$ & $2932 \mathrm{sh}$ & - & $2928 \mathrm{sh}$ & - & - & - & $2929 \mathrm{~m}$ & - & $v_{\text {as }}\left(\mathrm{CH}_{3}\right)$ \\
\hline 2872 vs & $2872 \mathrm{~s}$ & $2883 \mathrm{~m}$ & - & $2882 \mathrm{~m}$ & $2880 \mathrm{w}$ & $2889 \mathrm{~m}$ & $2878 \mathrm{bm}$ & $2879 \mathrm{~m}$ & - & $v_{\mathrm{s}}\left(\mathrm{CH}_{2}\right)$ \\
\hline $2823 \mathrm{sh}$ & $2823 \mathrm{~s}$ & $2831 \mathrm{sh}$ & - & $2830 \mathrm{sh}$ & $2828 \mathrm{w}$ & $2824 \mathrm{sh}$ & - & $2826 \mathrm{sh}$ & $2841 \mathrm{bm}$ & $v_{\mathrm{s}}\left(\mathrm{CH}_{2}\right)$ \\
\hline $1470 \mathrm{sh}$ & 1471 vs & $1471 \mathrm{sh}$ & $1479 w$ & $1471 \mathrm{sh}$ & - & $1462 \mathrm{~m}$ & - & - & - & $\delta_{s}\left(\mathrm{CH}_{2}\right)$ \\
\hline 1455 vs & 1451 vs & $1457 \mathrm{~m}$ & - & $1456 \mathrm{~m}$ & $1444 \mathrm{w}$ & - & $1452 \mathrm{~s}$ & $1457 \mathrm{~m}$ & $1445 \mathrm{bm}$ & $\delta\left(\mathrm{CH}_{3}\right)$ \\
\hline $1350 \mathrm{vs}$ & $1369 \mathrm{~m}$ & $1353 \mathrm{~m}$ & - & $1351 \mathrm{~m}$ & - & $1355 \mathrm{~m}$ & - & $1351 \mathrm{w}$ & $1366 \mathrm{w}$ & $w\left(\mathrm{CH}_{2}\right)$ \\
\hline $1299 \mathrm{~s}$ & $1286 \mathrm{~s}$ & $1287 \mathrm{~m}$ & $1279 w$ & $1286 \mathrm{~m}$ & $1296 \mathrm{sh}$ & $1288 \mathrm{w}$ & 1292 bm & - & $1296 \mathrm{w}$ & $w\left(\mathrm{CH}_{2}\right)$ \\
\hline $1247 \mathrm{~s}$ & $1244 \mathrm{~m}$ & $1249 \mathrm{~m}$ & - & $1250 \mathrm{~m}$ & - & $1249 \mathrm{~m}$ & - & - & - & $t\left(\mathrm{CH}_{2}\right)$ \\
\hline $1199 \mathrm{vs}$ & $1208 \mathrm{sh}$ & $1199 \mathrm{~m}$ & - & $1200 \mathrm{~m}$ & - & $1197 \mathrm{sh}$ & - & $1202 \mathrm{w}$ & - & $\delta\left(\mathrm{CH}_{3}\right)$ \\
\hline $1105 \mathrm{vs}$ & $1135 \mathrm{~s}$ & $1102 \mathrm{~m}$ & - & $1102 \mathrm{~m}$ & $1138 \mathrm{~m}$ & $1106 \mathrm{~m}$ & - & - & $1130 \mathrm{~m}$ & $v(\mathrm{C}-\mathrm{O})$ \\
\hline $1028 \mathrm{~m}$ & $1030 \mathrm{~m}$ & - & - & $1022 \mathrm{sh}$ & - & $1026 \mathrm{~m}$ & $1040 \mathrm{sh}$ & - & $1037 \mathrm{w}$ & $v_{\mathrm{s}}(\mathrm{C}-\mathrm{C})$ \\
\hline $943 \mathrm{~s}$ & $930 \mathrm{~m}$ & - & - & - & - & - & - & $951 \mathrm{sh}$ & - & $v_{\mathrm{s}}(\mathrm{C}-\mathrm{O}-\mathrm{C})$ \\
\hline 851 vs & 849 vs & $849 \mathrm{~m}$ & $842 \mathrm{vw}$ & $850 \mathrm{~m}$ & $850 \mathrm{~m}$ & $849 \mathrm{~m}$ & $841 \mathrm{~m}$ & $850 \mathrm{w}$ & 834 bm & $\rho\left(\mathrm{CH}_{2}\right)$ \\
\hline- & $811 \mathrm{sh}$ & - & $805 \mathrm{vw}$ & - & $812 \mathrm{w}$ & - & - & - & - & $\rho\left(\mathrm{CH}_{2}\right)$ \\
\hline- & $284 \mathrm{bm}$ & - & - & - & $282 \mathrm{bm}$ & - & - & - & 296 bm & $\delta(\mathrm{C}-\mathrm{O}-\mathrm{C})$ \\
\hline
\end{tabular}

v: very; s: strong; m: medium; w: weak; sh: shoulder; b: broad; $v$ : stretching; $\delta$ : in-plane bending; $\delta_{s}$ : scissoring; $w$ : wagging; $t$ : twisting; $\rho$ : rocking 
However, the strong and medium C-O stretching band of free PEGMME at 1060 (IR) $\mathrm{cm}^{-1}$ $1063(\mathrm{R}) \mathrm{cm}^{-1}$ have been observed at $1071 \mathrm{~cm}^{-1}, 1063 \mathrm{~cm}^{-1}$ and $1083 \mathrm{~cm}^{-1}$ for IR spectra of PEGMME adsorbed on $\mathrm{CaA}, \mathrm{NaX}$, and $\mathrm{NaY}$, respectively, and at $1067 \mathrm{~cm}^{-1}$ and $1046 \mathrm{~cm}^{-1}$ for Raman spectra of polymer adsorbed on NaX and ZSM-5, respectively. Similarly, the medium C-OC stretching band of free PEGMME (Silverstein and Webster, 1997; Stuart, 2004; Abdel-Mohsen et al., 2012) at 947 (IR) $\mathrm{cm}^{-1}-934$ (R) $\mathrm{cm}^{-1}$ has been only observed at $1021 \mathrm{~cm}^{-1}$ for the Raman spectrum of polymer adsorbed on $\mathrm{NaY}$ as a weak band and not observed for IR spectra. While most of the characteristic bands of PEGMME have been also observed in their adsorbed form on zeolites, the bending and stretching modes of the $\mathrm{OH}$ band have been not observed in any of the IR and Raman spectra.

On the other hand, the very strong C-O stretching band of free PEGMME at $1105 \mathrm{~cm}^{-1}$ for IR spectrum and strong for Raman spectrum at $1135 \mathrm{~cm}^{-1}$ have been observed as a medium band at 1102 $\mathrm{cm}^{-1}, 1102 \mathrm{~cm}^{-1}$ and $1106 \mathrm{~cm}^{-1}$ for IR spectra of PEGDME adsorbed on $\mathrm{CaA}, \mathrm{NaX}$, and $\mathrm{NaY}$, respectively, and at $1138 \mathrm{~cm}^{-1}$ and $1130 \mathrm{~cm}^{-1}$ for Raman spectra of PEGMME adsorbed on NaX and ZSM-5, respectively. Moreover, the C-O-C stretching band of PEGDME at $943 \mathrm{~cm}^{-1}$ has been observed as a shoulder at $951 \mathrm{~cm}^{-1}$ in the IR spectrum of ZSM-5. This band has not been observed in the Raman spectrum of any zeolite that adsorbed the PEGDME. Besides, C-O-C bending mode has been observed at $284 \mathrm{~cm}^{-1}, 282 \mathrm{~cm}^{-1}$ and $296 \mathrm{~cm}^{-1}$ as a broad medium band in the Raman spectra of pure PEGDME, the adsorbed form of NaX and ZSM-5, respectively. The shifts at the positions of most of the characteristic vibrational bands of polymer adsorbed on zeolites show the interaction between zeolites and polymers.

\section{Conclusions}

The peaks that did not exist before in the infrared spectra of zeolites but appear in the spectra after the polymers were adsorbed belong to the polymers. These peaks of polymers show that the adsorption process has taken place. The experimental IR and $\mu$-Raman spectral results of polyethylene glycol (monomethyl ether) and polyethylene glycol (dimethyl ether) adsorbed on the $\mathrm{CaA}, \mathrm{NaX}, \mathrm{NaY}$, and ZSM-5 synthetic zeolites indicate that the sources of adsorptions of polymers on title zeolites seem to be the interactions between the methylene and $\mathrm{OH}$ groups of polymers and oxygen atoms located in polymer chains and the non-acidic silanol hydroxyl group on the surface of the zeolites employing a hydrogen bond. 


\section{Acknowledgment}

The work was supported by the Unit of Scientific Research Projects of Süleyman Demirel University (Project No. 2102-D-10).

\section{Authors' Contributions}

All authors contributed equally to the study

\section{Statement of Conflicts of Interest}

There is no conflict of interest between the authors.

\section{Statement of Research and Publication Ethics}

The author declares that this study complies with Research and Publication Ethics.

\section{References}

Abdel-Mohsen, A. M., Aly, A. S., Hrdina, R. and El-Aref, A. T. (2012). A novel method for the preparation of silver/chitosan-O-methoxy polyethylene glycol core shell nanoparticles. Journal of Polymers and the Environment, 20(2), 459-468.

Bleken, F., Skistad, W., Barbera, K., Kustova, M., Bordiga, S., Beato, P., Lillerud, K. P., Svelle, S. and Olsbye, U. (2011). Conversion of methanol over 10-ring zeolites with differing volumes at channel intersections: comparison of TNU-9, IM-5, ZSM-11 and ZSM-5. Physical Chemistry Chemical Physics, 13(7), 25392549.

Cejka J. (2007). Introduction to Zeolite Science and Practice; 3rd Revised Edition; Studies in Surface Science and Catalysis, Volume 168, Oxford, UK, Elsevier.

Çiçek, E., Bardakçı, B., Ucun, F. and Bahçeli, S. (2003). Adsorption of trimethyl phosphite on H-KA, H-NaA, H-CaA and H-NaX zeolites: an IR study. Zeitschrift für Naturforschung A, 58a(5-6), 313-316.

Cundy, C. S. and Cox, P. A. (2003). The hydrothermal synthesis of zeolites: history and development from the earliest days to the present time. Chemical Reviews, 103(3), 663-702.

Franus, W., Wdowin, M. and Franus, M. (2014). Synthesis and characterization of zeolites prepared from industrial fly ash. Environmental Monitoring and Assessment, 186, 5721-5729.

Hunger, M., (1997). Bransted acid sites in zeolites characterized by multinuclear solid-state NMR spectroscopy. Catalysis Reviews - Science and Engineering, 39(4), 345-393.

Kumar, N., Dipak, P., Tiwari, D. C. And Tomar, R. (2020). Study and characterization of polyaniline/zeoliteMor nanocomposite and their role in detection of chemical warfare agent simulant-CEES. Chemical Physics Letters, 755, 137766.

Marković, M., Daković, A., Rottinghaus, G. E., Petković, A., Kragović, M., Krajišnik, D., and Milić, J. (2017) . Ochratoxin A and zearalenone adsorption by the natural zeolite treated with benzalkonium chloride. Colloids and Surfaces A: Physicochemical and Engineering Aspects, 529, 7-17.

Öztürk, N., Çırak, Ç. and Bahçeli, S. (2007). FT-IR spectroscopic study of 1,5-pentanedithiol and 1,6hexanedithiol adsorbed on $\mathrm{NaA}, \mathrm{CaA}$ and $\mathrm{NaY}$ zeolites. Zeitschrift für Naturforschung A, 60a (2005) 633-636. 
Öztürk, N., Ucun, F., and Bahçeli, S. (2010). Infrared Spectroscopy of 2-and 4-Trifluoromethylbenzaldebydes Adsorbed on Zeolites CaA, NaX and ZSM-5. Journal of Natural \& Applied Sciences, 14(1), 1-3.

Öztürk, N., Ucun, F., Muhtar, A. D. and Bahçeli, S. (2009). Infrared and SEM analyses of Polyethyleneglycol400 adsorbed on zeolites NaA, CaA, NaX and NaY. Journal of Molecular Structure, 922(1-3), 35-38.

Şen, S., Bardakçı, B., Yavuz, A. G., Gök, A. U. (2008). Polyfuran/zeolite LTA composites and adsorption properties. European polymer journal 44(8), 2708-2717.

Sherman, J. D. (1999). Synthetic zeolites and other microporous oxide molecular sieves. Proceedings of the National Academy of Sciences of the USA, 96(7), 3471-3478.

Silverstein, R. M. and Webster, F. X. (1997). Spectroscopic Identification of Organic Compound, sixth ed., New York, John Wiley \& Sons.

Stuart, B. H. (2004). Infrared Spectroscopy: Fundamentals and Applications. England, John Wiley \& Sons.

Thomas, J. M. and Klinowski, J., Systematic enumeration of microporous solids: towards designer catalysts. Angewandte Chemie International Edition, 46, 7160-7163.

Velvarská, R., Tišler, Z., Raichlová, V. and Hidalgo-Herrador, J. M. (2020). Raman Spectroscopy as Molybdenum and Tungsten Content Analysis Tool for Mesoporous Silica and Beta Zeolite Catalysts. Molecules, 25(21), 4918. 